DOI: 10.34015/2523-4552.2021.3.12

УДК 351.7:614.2

Ліненко О. I., аспірант Академії праці, соціальних відносин і туризму ORCID: 0000-0001-9090-1926

\title{
АДМІНІСТРАТИВНО-ПРАВОВЕ РЕГУЛЮВАННЯ МЕДИЧНОГО ЗАБЕЗПЕЧЕННЯ ВІЙСЬКОВОСЛУЖБОВЦІВ
}

У статті розкрито зміст адміністративно-правового регулювання медичного забезпечення військовослужбовців Збройних Сил України та інших силових формувань, утворених відповідно до законодавства України. Автор висвітлює роль та значимість в українському законодавстві організаційних заходів щодо збереження й зміцнення здоров'я військовослужбовців, що у свою чергу, сприяє вдосконаленню медичного забезпечення військ в умовах бойових дій та місцях постійної дислокації підрозділів.

Ключові слова: адміністративно-правове регулювання; медичне забезпечення військовослужбовців; Збройні Сили України.

В статье раскрывается содержание административно-правового регулирования медицинского обеспечения военнослужащих Вооруженных Сил Украины и других силовых формирований, созданных в соответствии с законодательством Украины. Автор научной статьи освещает роль и важную значимость в украинском законодательстве организационных мер, касающихся сохранения и укрепления здоровья военнослужащих, что в свою очередь способствует совершенствованию медицинского обеспечения войск в условиях боевых действий и местах постоянной дислокации подразделений.

Ключевые слова: административно-правовое регулирование; медицинское обеспечение военнослужащих; Вооруженные Силы Украины.

Постановка проблеми. 3 початком бойових дій на Сході України, українська держава приділяе велику увагу громадянам які проходять військову службу у військових формуваннях, оскільки військовослужбовці - це добре підготовлений контингент, який має широкі права на отримання матеріальних і соціальних привілеїв. На сьогоднішній день державна політика в галузі охорони здоров'я формується 3 урахуванням того факту, що проблеми охорони здоров'я людини - це найважливіший фактор національної безпеки. Адміністративноправове регулювання медичної допомоги військовослужбовців сприяє збереженню і підвищенню боєготовності Збройних Сил України та інших військових формувань, утворених відповідно до законодавства України, а тому, організаційні заходи щодо охорони здоров'я військовослужбовців, вирішують низку завдань, спрямованих на збереження i зміцнення здоров'я військовослужбовців та вдосконалення медичного 
забезпечення військ в умовах бойових дій.

Військова служба в умовах сьогодення, $\epsilon$ важливою i невід'ємною складовою сучасного суспільного життя. Як відомо, статус військовослужбовця - це особливий статус громадянина, наділений особливими правами і обов'язками. Присягаючи на вірність державі, вступаючи на службу до лав Збройних сили України або інших військових формувань, громадянин одразу стає частиною системи сектору безпеки країни, покликаної забезпечувати іiі обороноздатність і територіальну цілісність.

Відповідно до Конституції України, найбільшою соціальною цінністю держави, є людина, її життя і здоров'я, честь і гідність, недоторканість і безпека $[1$, с. 3]. Кожен громадянин має право на охорону здоров'я, медичну допомогу та медичне страхування. Охорона здоров'я забезпечується державним фінансуванням відповідних соціальноекономічних, медико-санітарних і оздоровчо-профілактичних програм [1, с. 49].

Бойові дії на сході України, відповідно до політично-правової та військової термінології, на сьогоднішній день мають чіткі ознаки неоголошеної гібридної війни, яка ведеться шляхом відкритих бойових дій різної інтенсивності, проведення диверсійно-розвідувальних операцій, інформаційної війни та економічного протистояння на регіональному та міжнародному рівнях, сепаратизмy. [2]

Війна, незалежно від їі масштабів та проявів, $\epsilon$ катастрофою для будь-якої держави та іï суспільства, що, як наслідок, приведе до фор- мування негативного міжнародного авторитету, глибокої економічної кризи, падіння соціальних стандартів, непоправних людських втрат, вимушеної міграції та еміграції, стрімким політичним та соціальноекономічним змінам, породженню деструктивним соціальним емоціям, а також негативним настроям серед населення, що накладає психологічний відбиток на свідомість багатьох поколінь. Саме тому, в умовах загрози національній безпеці на передній план виходить роль військовослужбовця, його професійні навички та соціальні гарантії, які в ході виконання службових обов'язків, змушують його ризикувати власним життям.

Однією із важливих складових соціальних гарантій військовослужбовців $€$ їх медичне забезпечення, оскільки лікувально-профілактичні заходи та реабілітація поранених військовослужбовців вимагають значних фінансових та ресурсних витрат держави. Зазначена категорія громадян одразу стає пріоритетною в системі охорони здоров'я [3, с.23]. Тому 3 метою покращення умов медичного забезпечення військовослужбовців, що безпосередньо приймають участь у бойових діях, Президент України підписав Указ Про рішення Ради національної безпеки $\mathrm{i}$ оборони України від 25 березня 2021 року «Про Стратегію воєнної безпеки України», яка безпосередньо відповідає за модернізацію системи медичного забезпечення військових підрозділів, та направлена на покращення якості медичного забезпечення шляхом впровадження новітніх систем, ефективних новітніх технологій і стандартів медичного забезпечення військ, максимально набли- 
жених до стандартів цивільної системи охорони здоров'я іноземних країн членів НАТО [4].

Постановка завдання. Мета статті - здійснення комплексного аналізу адміністративно-правового регулювання медичного забезпечення військовослужбовців на законодавчому рівні України, виявлення проблемних питань та розробка пропозицій щодо їх вирішення.

Аналіз останніх досліджень і публікацій. Проблематику адміністративно-правового регулювання медичного забезпечення військовослужбовців досліджували В. О. Жаховський, Л.Б.Мазур, Ю.В.Вороненко, А. Б. Зіменковський, Г. Ситник, О. Г. Шекера, В. Л. Савицький.

Виклад основного матеріалу. Надання якісної медичної допомоги пораненим військовослужбовцям, проведеним в умовах ведення бойових дій на сході країни, їх повноцінне лікування і реабілітація із застосуванням новітніх технологій $є$ найвищим пріоритетом держави. Належна організація надання якісної i своєчасної медичної допомоги пораненим, швидка евакуація військовослужбовців, їх подальше лікування та реабілітація забезпечують не лише збереження їхнього життя, але й швидке відновлення боєздатності [5, c. 65].

Система правового регулювання повсякденної діяльності військовослужбовців забезпечується нормативно-правовими актами військового права, які відповідно до їхньої юридичної сили та юридичної форми в ієрархічній структурі розподіляються наступним чином: 1) Конституція України; 2) конституційні (органічні) закони; 3) звичайні закони; 4) Укази Прези- дента України; 5) постанови Верховної Ради України; 6) постанови Кабінету Міністрів України; 7) розпорядження Кабінету Міністрів України; 8) нормативно-правові акти центральних органів виконавчої влади або ж відомчі нормативноправові акти: накази, директиви, розпорядження тощо; 9) накази, директиви, розпорядження начальника Генерального штабу ЗС України; 10) накази, директиви, розпорядження командувачів видів військ 3С України; 11) накази, директиви, розпорядження командувачів оперативних командувань $3 \mathrm{C}$ України; 12) накази, директиви, розпорядження начальників територіальних (регіональних) управлінь військових формувань, які не входять до складу 3С України, а також накази, директиви, розпорядження Міністра оборони України і інших силових формувань, утворених відповідно до законодавства України. Саме тому, на думку багатьох наукових авторів, для комплексного адміністративноправового врегулювання медичного забезпечення військовослужбовців різних військових формувань необхідно першочергово доопрацювати нормативно-правову базу законодавчих ініціатив, які б у повній мірі відповідали своєчасним комплексним змінам та враховували попередній позитивний досвід. [6, с. 31].

Ужиті Міністерством оборони України та органами управління медичного забезпечення різних рівнів заходи дозволили суттєво поліпшити стан медичного забезпечення військ на адміністративноправовому рівні, проте повноцінного вирішення виявлених проблемних питань так і не вдалося із-за відсутності повноцінного фінансування. 
Турбота щодо збереження та зміцнення здоров'я військовослужбовців - в першу чергу це обов'язок кожного командира підрозділу або начальника. Саме на керівників підрозділів покладається уся відповідальність за дотриманням вимог безпеки під час проведення навчань, заходів бойової та спеціальної підготовки, в ході експлуатації озброєння і військової техніки, проведення робіт та виконання інших обов'язків військової служби [7, с. 20].

3 метою повноцінного та якісного проведення медичного огляду військовослужбовців для визначення ступеня придатності проходження військової служби, визначено відповідний правовий механізм - військово-лікарську експертизу, яку проводять військово-лікарські комісії (Наказ Міністра оборони України «Положення про військово-лікарську експертизу в Збройних Силах України» від 14.08.2008 №402, зареєстрованого в Мін'юсті України 17.11.2008 за №1109/15800) [8].

У системі МВС діє аналогічний відповідний порядок (Наказ Міністра внутрішніх справ України «Про затвердження Порядку проведення обов'язково попереднього i періодичних медичних оглядів (диспансеризації) у закладах охорони здоров'я МВС» від 01.11.2016 №1146, зареєстровано в Міністерстві юстиції України від 29.11.2016 р. за №1543/29673) [9].

Адміністрацією Державної прикордонної служби України механізм медичного огляду у Держприкордонслужбі Наказ Голови Державної прикордонної служби України «Положення про проходження медичного огляду у Державній прикордонній службі України» від 06.05.2009 №333, зареєстровано в Мін'юсті України 26.06.2009 за №570/16586 [10].

Медичне забезпечення в системі Службі безпеки України здійснюється відповідно до Наказу Служби безпеки України «Про затвердження Інструкції про організацію медичного забезпечення у Службі безпеки України» від 21.12.2017 № 740, зареєстровано в Мін'юсті України 18.01.2018 р. за № 78/31530) [11].

Медичне забезпечення миротворчих контингентів і персоналу здійснюється відповідно до Положення про організацію медичного забезпечення військовослужбовців Збройних Сил України, які залучаються до участі в міжнародних операціях з підтримання миру і безпеки (Наказ Міністра оборони України від 15.04.2021 №99, зареєстровано в Міністерстві юстиції України 07 червня 2021 р. за № 761/36383) [12].

У разі відсутності за місцем проходження військової служби або за місцем проживання військовослужбовців військово-медичних закладів охорони здоров'я чи відсутності відповідних відділень або спеціального медичного обладнання, а також у невідкладних випадках медична допомога надається державними або комунальними закладами охорони здоров'я за рахунок Міністерства оборони України, інших утворених відповідно до законів України військових формувань та правоохоронних органів. Порядок розрахунку у даному випадку визначено постановою Кабінету Міністрів України «Про порядок надання медичної допомоги у військово-медичних закладах і 
взаєморозрахунків за неї між військовими формуваннями від 18.10.1999 №1923» [13].

Учасники бойових дій, а також прирівняні до них особи, особи які були звільнені з військової служби, які приймали безпосередню участь в бойових діях в ході проведення «Операції об'єднаних сил», у здійсненні заходів із забезпечення національної безпеки і оборони у Донецькій та Луганській областях або виконували службово-бойові завдання в екстремально-бойових умовах, в обов'язковому порядку повинні пройти безкоштовну психологічну, медико-психологічну реабілітацію у відповідних центрах 3 відшкодуванням вартості проїзду до фахових центрів оздоровчого типу і назад. Порядок проведення реабілітації та відшкодування вартості проїзду встановлюються Кабінетом Міністрів України [14].

Б. О. Логвиненко стверджує, що, гарантоване Конституцією право на безоплатну медичну допомогу не може бути заміщене повною оплатою надання медичних послуг та лікарських засобів за рахунок коштів Державного бюджету України, що передбачені програмою медичних гарантій. Видається очевидним, що програми можуть змінюватись залежно від волі суб'єкта владних повноважень у сфері охорони здоров'я, а конституційна норма - ні [15].

Аналізуючи досвід США щодо адміністративно-правового регулювання медичної допомоги військовослужбовцям, у першу чергу грунтується на вимогах відкритого та чесного діалогу між пацієнтом та законодавством. Більшість медичних установ США одразу надають пацієнтам інформаційний лист, де коротко та змістовно пояснюються їх права та обов'язки [16].

Важливим механізмом впливу держави на якість надання медичної допомоги є стандартизація медичного забезпечення. Вона спрямована на досягнення належного рівня впорядкування безпосередньо в системі охорони здоров'я. Це може бути досягнуто шляхом розробки і впровадження відповідних норм та правил, які застосовуються в системі охорони здоров'я [17, с. 109].

На даний час Міністерством охорони здоров'я України виконується Галузева програма стандартизації медичної допомоги населенню України. Це сприяло розробленню та впровадженню низки медикотехнологічних документів, у тому числі стандартів на ресурси охорони здоров'я та технологічні стандарти $[18$, с. 50$]$.

Цьому передувало чисельні наукові дослідження, проведені науковцями. Однак, питання щодо стандартизації медичної допомоги пораненим під час бойових дій військовослужбовцям, підготовки військових медичних фахівців та забезпечення їх медичним майном до цього часу не розглядались.

Практично не досліджувалося питання розробки сучасних стандартів до якості надання медичної допомоги у Збройних Силах України.

Стандартизащія - діяльність, спрямована на напрацювання та затвердження певних правил для загального та неодноразового використання щодо вже встановлених чи тих, що будуть встановлені у майбутньому завдань і спрямована на досягнення належного ступеня впорядкованості в певній сфері [18, c. 49]. 
Мета стандартизації надання медичної допомоги полягає у такому: забезпечення відповідності об'єктів стандартизації своєму призначенню;

керування різноманітністю, застосовністю, сумісністю, взаємозамінністю об'єктів стандартизації; забезпечення раціонального виробництва шляхом застосування визнаних правил, настанов і процедур;

забезпечення охорони життя та здоров'я;

забезпечення прав та інтересів споживачів;

забезпечення безпечності праці;

збереження навколишнього природного середовища і економія всіх видів ресурсів;

усунення технічних бар'єрів у торгівлі та запобігання їх виникненню, підтримка розвитку і міжнародної конкурентоспроможності продукції [19].

Питання стандартизації медичного забезпечення Збройних сил України $\epsilon$ надзвичайно важливим та актуальним.

Зміни воєнно-політичної обстановки у світі свідчать про їі напруженість, динамічний та нестабільний характер. Провідні держави збільшують розміри воєнних витрат, активізують розробку нових зразків озброєння, підвищують інтенсивність військових навчань. Воєнна сила продовжує залишатися визначальним елементом спроможності будь-якої країни відстоювати свої національні інтереси [20, с. 10].

У зв'язку з цим, в Україні відбувається системне реформування у сфері національної безпеки та оборони, що висуває високі вимоги до медичного забезпечення Збройних Сил України зокрема. Однак, ще недостатньо проводиться реформування щодо стандартизації медичного забезпечення у військових формуваннях.

Так, основним рішенням цього питання може бути створення системи стандартизації у медичній галузі Збройних Сил України, яка б полягала в забезпеченні належної якості лікувально-профілактичних, санітарно-гігієнічних, протиепідемічних та інших заходів процесу медичного забезпечення шляхом якісного рівня організації, наявністю сучасного технічного оснащення, всебічного ресурсного забезпечення, високого рівня підготовки медичних працівників на базі передових науково-теоретичних розробок через створення системи медичного забезпечення Збройних Сил України у відповідності до нових соціально-економічних умов i сучасних завдань бойової підготовки військ [21].

Разом $з$ тим, з метою набуття Україною критеріїв, які необхідні для вступу до Європейського Союзу та НАТО, забезпечення, при цьому, рівноправного та взаємовигідного співробітництва у воєнній, воєнноекономічній та військово-технічній сферах 3 державами-партнерами, Збройні Сили України цікавляться досвідом військово-медичних служб армій інших держав, насамперед держав-членів НАTO, у яких система медичної стандартизації розвинена на досить високому рівні. Це робиться 3 метою використання цього досвіду у проведенні відповідної реформи у системі медичного забезпечення Збройних Сил України шляхом поступового прийняття стандартів 
HATO, а також налагодження взаємосумісності між Збройними Силами України та НАТО [22].

У зв'язку з цим, військова система медичного забезпечення спрямована на необхідність уніфікації сумісності, принципів та військових стандартів медичного забезпечення Збройних Сил України 3 відповідними принципами і стандартами Північноатлантичного альянсу [23].

Висновки. Військовослужбовець - це особа, яка виконує посадові обов'язки пов'язані з проходженням військової служби i покликана вирішувати завдання у сфері безпеки та оборони держави, у зв'язку з чим має спеціальний правовий статус. Саме тому медичне забезпечення військовослужбовців, $\epsilon$ одним із пріоритетних напрямів що поліпшують умови проходження військової служби та виступає важливим чинником, що піднімає престиж військової служби серед населення.

Адміністративно-правове регулювання реалізації права на охорону здоров'я військовослужбовців, здійснюється за допомогою комплексу спрямованих заходів системою уповноважених суб'єктів, що здійснюють цілеспрямований вплив на стан забезпечення реалізації права на охорону здоров'я за допомогою норм права, і у свою чергу складаються із засобів, форм i методів адміністративно правового впливу.
Якісна медична послуга є однією 3 ключових позицій в оцінці медичного обслуговування і досягається шляхом поєднання комплексу реальних технологій (які мають позитивну оцінку від споживачів медичної послуги) та нормативноправовою базою що регулює дані процеси (порядок яких регламентує та охоплює законодавча база механізм використання наявних ресурсів).

Найбільш дієвою в системі медичного забезпечення Збройних Сил України $є$ система стандартизації держав-членів НАТО, де військові стандарти медичного забезпечення рівні або вищі за національні цивільні стандарти. Стандарти медичного забезпечення воєнного часу повинні відповідати стандартам мирного часу, а національні військові стандарти медичного забезпечення повинні бути близькими до міжнародних або відповідати їх стандартам.

Реформування системи медичного забезпечення Збройних Сил України повинно здійснюватися шляхом створення єдиної уніфікованої системи стандартизації медичного забезпечення Збройних Сил України, яке повинно відбуватися з урахуванням інтеграції медичного забезпечення Збройних Сил України в загальнодержавну систему охорони здоров'я та досвіду держав-членів HATO.

\section{Список використаних джерел}

1. Конституція України URL: https: //zakon.rada.gov.ua/laws/show/254\%D0\%BA/ 96-\%D0\%B2\%D1\%80\#Text (дата звернення 20.10.2021).

2. Гібридна війна. Вікіпедія URL: https://uk.wikipedia.org/wiki/Гібридна_війна (дата звернення 20.10.2021).

3. Бадюк М.І. Актуальність підготовки військовослужбовців Збройних Сил України як одного з пріоритетних напрямків підвищення якості надання домедичної до- 
помоги пораненим в умовах сучасних збройних конфліктів. Матеріали конференції «Актуальні інфекційні захворювання: клініка, діагностика, лікування, профілактика». Київ, 2015. С. 22 - 23.

4. Указ Про рішення Ради національної безпеки і оборони України від 25 березня 2021 року «Про Стратегію воєнної безпеки України» URL: https://zakon.rada.gov.ua/laws/show/121/2021\#n8 (дата звернення 20.10.2021).

5. Степаненко А.В., Сміянов В.А. Управління якістю медичної допомоги в закладі охорони здоров'я. Східноєвроп. журн. громад. здоров'я. 2012. № 2-3. С. 64 - 67.

6. Верба А. В., Жаховський В. О., Лівінський В. Г. Досвід медичного забезпечення антитерористичної операції та шляхи його вдосконалення. Наука і оборона. 2015. № 3-4. С. 28-33.

7. Мазур Л.Б. Загальна характеристика забезпечення права військовослужбовців на охорону здоров'я у Збройних Силах України. Правове життя: сучасний стан та перспективи розвитку: матеріали міжнародної науково-практичної конференції (м. Запоріжжя, 29-30 травня 2015 року). Запоріжжя: Запорізька міська громадська організація «Істина», 2015. С. 19-21.

8. Наказ МО України від 14.08.2008 № 402 «Про затвердження Положення про військово-лікарську експертизу в Збройних Силах України». URL: https://zakon.rada.gov.ua/laws/show/z1109-08\#Text (дата звернення 20.10.2021).

9. Наказ Міністра внутрішніх справ України «Про затвердження Порядку проведення обов'язково попереднього і періодичних медичних оглядів (диспансеризації) у закладах охорони здоров’я МВС» від 01.11.2016 №1146, зареєстровано в Міністерстві юстиції України від 29.11.2016 р. за №1543/29673 URL: https://zakon.rada.gov.ua/laws/show/z1543-16\#Text (дата звернення 20.10.2021).

10. Наказ Голови Державної прикордонної служби України «Положення про проходження медичного огляду у Державній прикордонній службі України» від 06.05.2009 №333, зареєстровано в Мін’юсті України 26.06.2009 за №570/16586 URL: http://search.ligazakon.ua/l_doc2.nsf/link1/RE16586.html (дата звернення 20.10.2021).

11. Наказ «Про затвердження Інструкції про організацію медичного забезпечення у Службі безпеки України» від 21.12.2017 №740, зареєстровано в Мін'юсті України 18.01.2018 р. за № 78/31530) URL: https://zakon.rada.gov.ua/ laws/show/z1238-07\#Text (дата звернення 20.10.2021).

12. Наказ Міністра оборони України від 15.04.2021 №99, зареєстровано в Міністерстві юстиції України 07 червня 2021 р. за № 761/36383 URL: http://search.ligazakon.ua/l_doc2.nsf/link1/RE36383.html (дата звернення 20.10.2021).

13. Постанова від 18 жовтня 1999 р. N 1923 «Про затвердження Порядку надання медичної допомоги у військово-медичних закладах і взаєморозрахунків за неї між військовими формуваннями» URL: https://zakon.rada.gov.ua/laws/show/1923-99\%D0\%BF\#Text (дата звернення 20.10.2021).

14. Науково-практичний коментар Закону України «Про соціальний та правовий захист військовослужбовців та членів їх сімей» (2-е видання, доповнене), Львів. 2019.

15. Логвиненко Б. О. Безсистемність у системі охорони здоров'я як головна проблема сьогодення. Дніпровський науковий часопис публічного управління, психології, права. 2020 № 1. С. 50-55.

16. Исследовательская служба Конгресса (2018-04-20). «Учебник по обороне: военная система здравоохранения».

17. Вороненко Ю.В. Методичні підходи до впровадження стандартизації організаційних технологій у систему управління якістю медичної допомоги / Ю. В. Вороненко, В. В. Горачук. Укр. мед. часопис. IX/X. 2012. № 5 (91). С. 108-110. 
18. Зіменковський А.Б. Сучасні реалії та перспективи нормативноправової бази системи стандартизації в охороні здоров'я України. Клінічна фармація, фармакотерапія та медична стандартизація. 2008. № 1. С. 49-54.

19. Закон України «Про стандартизацію» від 5.06.2014 р. № 1315-VII URL: http://zakon5.rada.gov.ua/laws/show/1315-18 (дата звернення 20.10.2021).

20. Ситник Г. Пріоритети державної політики у воєнній безпеці. Військо України. 2012. № 3 (139). С 8-11.

21. Шекера О.Г. Стратегічний курс медичного забезпечення збройних сил країн НАТО. В кн.: Вісник наукового інформаційно-аналітичного центру НАТО Прикарпатського національного університету імені Василя Стефаника. Івано-Франківськ, 2009. Випуск 2.161 с.

22. Матеріали семінару із стандартизації НАТО. Київ: УкрНДІССІ, 2002. 48 с.

23. Савицький В.Л., Власенко О. М., Стриженко В. І., Булах О. Ю. Система медичного забезпечення військ (сил) - складова загальнодержавної політики охорони здоров’я громадян України. Наука і оборона. Київ, 2014. № 2. С. 27-33.

\section{References}

Badyuk, M. I. (2015). Aktualnist pidgotovki vijskovosluzhbovciv Zbrojnih Sil Ukrayini yak odnogo $\mathrm{z}$ prioritetnih napryamkiv pidvishennya yakosti nadannya domedichnoyi dopomogi poranenim v umovah suchasnih zbrojnih konfliktiv. Materiali konferenciyi «Aktualni infekcijni zahvoryuvannya: klinika, diagnostika, likuvannya, profilaktika». Kiyiv, 22 -23 .

Stepanenko, A. V., Smiyanov, V. A. (2012). Upravlinnya yakistyu medichnoyi dopomogi v zakladi ohoroni zdorov'ya. Shidnoyevrop. zhurn. gromad. zdorov'ya, 2-3, 64-67.

Verba, A. V., Zhahovskij, V. O., Livinskij, V. G. (2015). Dosvid medichnogo zabezpechennya antiteroristichnoyi operaciyi ta shlyahi jogo vdoskonalennya. Nauka i oborona, 3-4, 28-33.

Mazur, L. B. (2015). Zagalna harakteristika zabezpechennya prava vijskovosluzhbovciv na ohoronu zdorov'ya u Zbrojnih Silah Ukrayini. Pravove zhittya: suchasnij stan ta perspektivi rozvitku: materiali mizhnarodnoyi naukovo-praktichnoyi konferenciyi (m. Zaporizhzhya, 29-30 travnya 2015 roku). Zaporizhzhya: Zaporizka miska gromadska organizaciya «Istina», 19-21.

Logvinenko, B. O. (2020). Bezsistemnist u sistemi ohoroni zdorov'ya yak golovna problema sogodennya. Dniprovskij naukovij chasopis publichnogo upravlinnya, psihologiyi, prava, 1, 50-55.

Voronenko, Yu. V. (2012). Metodichni pidhodi do vprovadzhennya standartizaciyi organizacijnih tehnologij u sistemu upravlinnya yakistyu medichnoyi dopomogi / Yu.V. Voronenko, V.V. Gorachuk. Ukr. med. chasopis. IX/X, 5 (91), 108-110.

Zimenkovskij, A. B. (2008). Suchasni realiyi ta perspektivi normativnopravovoyi bazi sistemi standartizaciyi v ohoroni zdorov'ya Ukrayini. Klinichna farmaciya, farmakoterapiya ta medichna standartizaciya, 1, 49-54.

Sitnik, G. (2012). Prioriteti derzhavnoyi politiki u voyennij bezpeci. Vijsko Ukrayini, 3 (139), 8-11.

Shekera, O. G. (2009). Strategichnij kurs medichnogo zabezpechennya zbrojnih sil krayin NATO. V kn.: Visnik naukovogo informacijno-analitichnogo centru NATO Prikarpatskogo nacionalnogo universitetu imeni Vasilya Stefanika. Ivano-Frankivsk, 2.

Savickij, V. L., Vlasenko, O. M., Strizhenko, V. I., Bulah, O. Yu. (2014). Sistema medichnogo zabezpechennya vijsk (sil) - skladova zagalnoderzhavnoyi politiki ohoroni zdorov'ya gromadyan Ukrayini. Nauka i oborona. Kiyiv, 2, 27-33. 
A. Linenko, Postgraduate student of the Academy of Labor, Social Relations and Tourism

ORCID: 0000-0001-9090-1926

\section{Administrative and legal regulation of medical support of military servants}

Military service requires a person to give himself completely. The impact on the body of a serviceman of the conditions of service in his daily activities is not always positive, in this regard, since ancient times people are warriors, retired and crippled in wars, did not go unnoticed and concerned about society and the state. In this activity, the most important thing is how the legislative and administrative regulation is carried out to ensure and protect the basic rights of servicemen to receive medical care.

Such regulation is carried out on the basis of laws which, from the point of view of the theory of law, have the highest legal force in the form of normative legal acts which are accepted in a special order by public authorities. At the same time, the laws adopted by the Verkhovna Rada of Ukraine or local self-government bodies, above all, reflect the interests of civil society.

The exercise of the right to health care by servicemen is carried out in specific conditions due to the special nature of the tasks assigned to them, the performance of which is sometimes associated with the need for unquestioning performance of tasks in all conditions, including risk to life. In this regard, first of all, servicemen have the right to free medical care in military medical institutions. In the absence of military medical institutions at the place of military service or in the absence of appropriate departments or special medical equipment, as well as in emergencies, medical care is provided to them without hindrance and free of charge in health care facilities, regardless of their departmental affiliation and ownership. The servicemen undergo annual medical examinations and undergo treatment and prevention measures.

The article reveals the content of administrative and legal regulation of medical care for servicemen of the Armed Forces of Ukraine and other law enforcement agencies formed in accordance with the legislation of Ukraine. The author of the scientific article highlights the role and importance in Ukrainian legislation of organizational measures to preserve and strengthen the health of servicemen, which in turn contributes to improving the medical support of troops in hostilities and places of permanent deployment.

Keywords: administrative and legal regulation; medical support of servicemen; Armed Forces of Ukraine. 